\title{
Role of DPP-4 inhibitors in the management of type 2 diabetes
}

\author{
Ramesh*, D. D. Gupta
}

Department of Pharmacology, Indira Gandhi Medical College Shimla, Himachal Pradesh, India

Received: 15 October 2018 Accepted: 01 November 2018

\section{*Correspondence to: \\ Dr. Ramesh, \\ Email: rameshgulepa9674@ gmail.com}

Copyright: (C) the author(s), publisher and licensee Medip Academy. This is an openaccess article distributed under the terms of the Creative Commons Attribution NonCommercial License, which permits unrestricted noncommercial use, distribution, and reproduction in any medium, provided the original work is properly cited.

\begin{abstract}
Among various insulinotropic agents used in treatment of Type $2 \mathrm{DM}$, inclusion of DPP4 inhibitors are considered as major breakthrough as far as new drug development is concerned. In this review article we have discussed in detail about the pathogenesis of diabetes mellitus especially the role of incretin, DPP4 enzyme and implication of its inhibitors in treatment of DM. Also, various clinical studies regarding use of DPP4 inhibitors as monotherapy and as combination therapy with other antidiabetic agents were discussed. DPP-4 inhibitors control glucose in fasting as well as in postprandial state both in monotherapy and in combination with other oral antidiabetic agents. Significant reduction in HbA1c observed with DPP4 inhibitors as monotherapy. On combining DPP 4 inhibitor as add-on therapy to metformin, glitazone or sulphonylurea therapy in patients with type 2 diabetes not reaching therapeutic goals, DPP-4 inhibitors reduce HbA1c, fasting plasma glucose and 2-h postprandial plasma glucose up to the desired level. Various DPP-4 inhibitors have been proven to be as safe and tolerable both as monotherapy and combination with other antidiabetic agents. Inhibition of DPP4 enzyme has been proven as a promising aspect in the treatment of type 2 diabetes and various drugs inhibiting DPP4 enzymes have been developed now. They are highly recommended in the treatment of Type 2 DM both as monotherapy as well as combination therapy.
\end{abstract}

Keywords: Diabetes mellitus, DPP4 inhibitors, Incretin

\section{INTRODUCTION}

Metabolic abnormalities seen in individuals with type 2 diabetes mellitus (T2DM) are usually abnormalities in insulin secretion both qualitative and quantitative, insulin resistance, obesity, increased endogenous glucose production and dysregulation of other islet hormones secretion such as amylin and glucagon.

During recent development on diabetes research, another important abnormality, which has been encountered, is the decreased incretin effect due to impairment in secretion and action of the incretin hormones glucagon-like peptide1 (GLP-1) and glucose-dependent insulinotropic peptide (GIP). It has been recognized that glucose homeostasis is governed by a complex interaction among various mediators, including insulin, glucagon, amylin, and incretin hormones. Deficits in any one of these components may contribute to the pathophysiology of T2DM (Table 1). ${ }^{1}$

Large number of studies on drugs used in T2DM has been directed at increasing insulin secretion or sensitivity using various agents. A number of reviews on the effect of incretin-based therapies have been published. ${ }^{2}$

The present review examines the pathophysiology of T2DM, with a focus on understanding the incretin dysregulation and role of DPP-4 inhibitors in treatment of patients with Type $2 \mathrm{DM}$. 
Table 1: Effects of various hormones on glucose regulation.

\begin{tabular}{|c|c|c|}
\hline $\begin{array}{l}\text { Secreted } \\
\text { by }\end{array}$ & Hormone & Gluco-regulatory effects \\
\hline $\begin{array}{l}\text { Alfa } \\
\text { cells }\end{array}$ & Glucagon & $\begin{array}{l}\text { Increased glycogenolysis, } \\
\text { Enhances gluconeogenesis } \\
\text { and ketogenesis in liver. }\end{array}$ \\
\hline \multirow{2}{*}{$\begin{array}{l}\text { Beta } \\
\text { cells }\end{array}$} & Insulin & $\begin{array}{l}\text { Increased glucose uptake by } \\
\text { cells, decreases glucagon } \\
\text { secretion, promotes protein } \\
\text { and fat synthesis, }\end{array}$ \\
\hline & Amylin & $\begin{array}{l}\text { Decreases postprandial } \\
\text { glucagon release, slows down } \\
\text { gastric emptying, enhances } \\
\text { satiety and decreases weight }\end{array}$ \\
\hline Intestine & $\begin{array}{l}\text { GLP-1 } \\
\text { and GIP }\end{array}$ & $\begin{array}{l}\text { Increases glucose dependent } \\
\text { insulin secretion, decreases } \\
\text { glucagon synthesis, gastric } \\
\text { emptying and body weight. } \\
\text { Decreases B cell apoptosis }\end{array}$ \\
\hline
\end{tabular}

\section{The GI system and glucose homeostasis in the healthy state}

In glucose homeostasis, gastrointestinal system plays an integral role. In healthy individuals, it has been observed that orally administered glucose provides a stronger stimulus for insulin secretion than does an intravenous glucose. Incretin effect may be responsible for $50 \%$ to $70 \%$ of the total insulin secretion following oral glucose administration. This incretin effect is thought to be produced by GLP-1 and GIP (GI peptide hormones) which exert major Gluco-regulatory actions. ${ }^{3}$ These peptide hormones acts by binding to different receptors expressed on alpha, beta and delta cells present mainly on G.I system. Other sites for GLP-1 receptors are lung, heart, central nervous system (CNS) and peripheral nervous system whereas GIP receptors are expressed in adipose tissue and the $\mathrm{CNS}^{3}$

Fasting glucose is controlled by tonic secretion of insulin/glucagon, however excursions of glucose after meal (postprandial glucose) is controlled by insulin along with the incretin effect of G.I peptide hormones. Additionally, preclinical studies demonstrated the effect of GLP-1 to induce the transcription of the insulin gene and insulin biosynthesis, thus justifying the role of peptide hormones in increasing beta-cell proliferation and decreasing beta-cell apoptosis. ${ }^{4}$ Extra intestinal actions of GLP-1 are CNS-mediated insulin secretion, delaying gastric emptying, increasing CNS-mediated satiety leading to decreased food intake, indirectly increasing insulin sensitivity and nutrient uptake in skeletal muscle and adipose tissue also have some neuroprotective effects. ${ }^{5}$

\section{Role of the incretin pathway}

Until recently, the pathophysiology of type 2 diabetes mellitus (T2DM) is based on the triad of progressive decline in insulin-producing pancreatic beta cells, an increase in insulin resistance and increased hepatic glucose production. ${ }^{6}$ but it is well understood that other factors like defective actions of the gastrointestinal (GI) incretin hormones, glucagon-like peptide-1 (GLP-1) and glucosedependent insulinotropic polypeptide (GIP) also play significant role in pathogenesis of type 2 diabetes mallietus. A hypothesis based upon the observation that oral intake of glucose resulted in a greater insulin response when compared with intravenous glucose administration lead to the origin of a term 'incretin effect', which is the stimulation of insulin release by the oral intake of nutrients. Incretin hormones that attribute to this effect are glucose-dependent insulinotropic peptide (GIP), secreted mainly from duodenal $\mathrm{K}$ cells of the proximal small bowel, and glucagon-like peptide-1 (GLP-1), secreted from the enteroendocrine $\mathrm{L}$ cells of the distal gut. ${ }^{7}$

The physiological role of GLP-1are multiple in normal individuals which includes glucose-dependent insulin secretion, inappropriate glucagon secretion from the pancreas, and slowing of gastric emptying. ${ }^{8}$ Despite their therapeutic potential, most notably GLP-1, in the management of patients with type 2 diabetes, these endogenous GLP-1 and GIP are rapidly degraded by the enzyme DPP-4. ${ }^{7}$

The incretin effect has been demonstrated to be impaired in people with type 2 diabetes, which may contribute to the inability of these patients to secrete an adequate amount of insulin to meet physiologic needs. The pathophysiology of this deficient incretin response has not been entirely understood. Up to $60 \%$ insulin release to a given glucose load has been identified as incretin effect. ${ }^{9}$

\section{REVIEW OF LITRATURE}

\section{DPP 4 enzyme and its inactivation in type 2 DM}

Dipeptidyl peptidase (DPP)-4 is a complex enzyme that exists as a membrane-anchored cell surface peptidase that transmits intracellular signals via a short intracellular tail. Both glucose-dependent insulinotropic polypeptide (GIP) and glucagon-like peptide-1 (GLP-1) are endogenous physiological substrates for DPP-4, and chemical inhibition of DPP-4activity, or genetic inactivation of DPP-4in rodents, results in increased levels of intact bioactive GIP and GLP-1. Furthermore, mice and rats with genetic inactivation or inhibition of DPP-4 exhibit improved glucose tolerance, elevated levels of GLP-1 and GIP, and resistance to diet-induced obesity and hyperglycemia. The available preclinical data suggests that highly selective DPP-4 inhibition represents an effective and safe strategy for the therapy of type 2 diabetes.DPP-4 is a widely expressed cell surface peptidase that exhibits a complex biology encompassing cell membrane associated activation of intracellular signal transduction pathways, cell-cell interaction, and enzymatic activity exhibited by both the membrane-anchored and soluble forms of the enzyme. ${ }^{10}$ 
By blocking the enzymatic inactivation of the incretins, DPP-4 inhibitors make it possible for higher levels of active incretins to circulate and carry out their physiologic gluco-regulatory functions. Pharmacologically, selectivity for the DPP-4 inhibitors is important due to potential issues with safety and tolerability as enzyme has wide range of distribution. DPP 4 enzyme is found in highest concentration in the kidneys, intestines, and bone marrow, but it is also found in the liver, pancreas, placenta, thymus, spleen, epithelial cells, vascular endothelium, lymphoid and myeloid cells. ${ }^{11}$

This review explores the growing understanding of the role of the incretins in normal insulin secretion, as well as in the pathogenesis of T2DM, and examines the pathophysiologic basis for the benefits and therapeutic application of incretin-based therapies in T2DM.

\section{Chemical structure of DPP-4 inhibitor}

The DPP 4 inhibitors are broadly divided into two groups. First group comprise of nitrile containing compounds such as sitagliptin ( $\beta$-amino acid based) vildagliptin and saxagliptin they resemble the dipeptide structure of DPP4 substrates, whereas alogliptin (modified pyrimidinedione) and linagliptin (xanthine-based) constitute the second group, which are non-peptido mimetic (Figure 1). ${ }^{12-16}$ All compounds are competitivereversible inhibitors having high affinity for DPP4 enzyme. Various DPP 4 inhibitors interact differently at enzymatic sites as sitagliptin, alogliptin and linagliptin form non-covalent interactions with their residues. ${ }^{16}$ Whereas enzyme inhibition by vildagliptin and saxagliptin is a two-step process that involves the formation of a reversible covalent enzyme-inhibitor complex where binding as well as dissociation between enzyme and its inhibitor are a slow process, resulting in the enzyme slowly equilibrating between the active and inactive forms. ${ }^{17}$ This means that the catalytic activity will be inhibited even after the free drug has been cleared from the circulation, this explains why vildagliptin and saxagliptin inhibit DPP-4 activity for longer duration even after their shorter halflives.

\section{Pharmacological differences between DPP-4 inhibitors}

DPP-4 inhibitors have marked structural heterogeneity (Figure 1). This may account for variations in the pharmacokinetic profile between DPP-4 inhibitors. Linagliptin, has a unique xanthine-based structure has long terminal half-life (up to $184 \mathrm{~h}$ ), whereas the terminal halflife of sitagliptin is between 10 and $12 \mathrm{~h} .{ }^{18}$ Saxagliptin (half-life $2.5 \mathrm{~h}$ ) is metabolized by cytochrome P450 3A4/5 (CYP3A4/5) yields an active metabolite, which is about half as potent as the parent compound, with terminal halflives of $3.1 \mathrm{~h}$. However, the mean $\mathrm{t} 1 / 2$ value for plasma DPP-4 inhibition is $26.9 \mathrm{~h}^{19}$ In contrast; metabolites of linagliptin, vildagliptin and sitagliptin appear to be inactive. Therefore, linagliptin, sitagliptin and saxagliptin effectively control glycemia over $24 \mathrm{~h}$, despite the relatively short half-lives of the latter two agents. The structural heterogeneity of DPP-4 inhibitors probably accounts for variations in pharmacological potency of different compounds.

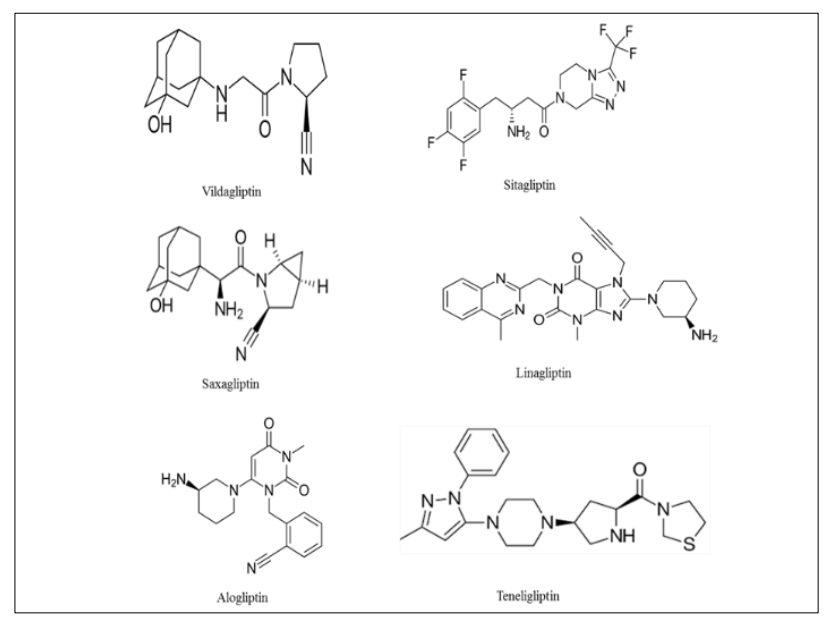

Figure 1: Chemical structure of DPP4 inhibitors.

In vitro, linagliptin inhibits DPP-4 (IC50approximately $1 \mathrm{nM})$ more potently than sitagliptin $(19 \mathrm{nM})$, alogliptin $(24 \mathrm{nM})$, saxagliptin $(50 \mathrm{nM})$ and vildagliptin $(62 \mathrm{nM}) .{ }^{20} \mathrm{In}$ rodent models, $24 \mathrm{~h}$ after linagliptin administration, the extent of DPP-4 inhibition and effects on glucose tolerance was greater than that produced by sitagliptin, alogliptin, saxagliptin and vildagliptin. In a study using Zucker diabetic fatty rats and mice with diabetes induced by a combination of high-fat diet and low-dose streptozotocin, linagliptin found to have better control on HbA1c and GLP-1 than vildagliptin. ${ }^{21}$ Since DPP-4 belongs to serine peptidases family, selective inhibition of DPP-4would be advantageous in order to avoid unexpected adverse effects. Teneligliptin is a new gliptin, has advantage over others in terms of its high efficacy and long duration of action. It has a long half-life of 26.9 hours and a convenient once-daily administration.

\section{Mode of action of DPP-4 inhibitors}

The biological half-life of circulating GLP-1 and GIP is very short because of the high affinity and activity of DPP4 towards these substrates. Therefore, native GLP-1 is not practical for therapeutic purposes, but DPP-4 inhibition offers a novel way to increase endogenous incretin concentrations as a treatment option. ${ }^{22}$

DPP-4 inhibitors are the first orally administered agents that modulate the physiology of GLP-1 by inhibiting the enzyme DPP-4. ${ }^{23}$ In contrast to other insulinotropic agents, for example the sulphonylureas, the insulinotropic effect of GLP-1 has more potential in managing optimum blood glucose concentration thus limiting the events of hypoglycaemias. It has the ability to restore the blunted first phase of insulin secretion in type 2 diabetes. ${ }^{23}$ GLP-1 has other 'noninsulinotropic' physiological actions that may be advantageous in type 2 diabetes therapy: it 
suppresses glucagon secretion from the alpha-cells and slows gastric emptying thus contributes to satiety and to a slower passage of carbohydrates. Additionally, GLP-1 contributes to satiety in the hypothalamus, where it is found as a neurotransmitter. Furthermore, it stimulates the process of beta-cell formation and also inhibits their apoptosis leading to an increase in beta-cell mass. ${ }^{23}$

Both sitagliptin and vildagliptin do not cause hypoglycaemia because they stimulate insulin secretion only under hyperglycaemic conditions. Also, they are not involved in drug-drug interactions, especially with other anti hyperglycaemic oral agents. ${ }^{24}$

DPP-4has high affinity for GLP-1 than for other peptides including GIP. DPP-4 belongs to an enzyme of endopeptidase family; therefore DPP-4 inhibitors need to have a high selectivity to inhibit DPP-4 exclusively and no other DPPs.

\section{Clinical studies with DPP-4 inhibitors}

DPP-4 inhibitors control glucose in fasting as well as in postprandial state both in monotherapy and in combination with other oral antidiabetic agents. They improve beta-cell functions, which is evident by improvement in parameters of postprandial insulin, C-peptide responses, HOMA-B and proinsulin/insulin ratio in patients with type 2 diabetes. $^{23,25}$ Treatment with DPP-4 inhibitors is weight neutral. ${ }^{25}$ On combining DPP 4 inhibitor as add-on therapy to metformin, glitazone or sulphonylurea therapy in patients with type 2 diabetes not reaching therapeutic goals, DPP-4 inhibitors reduce HbA1c, fasting plasma glucose and 2-h postprandial plasma glucose up to the desired level. ${ }^{26}$ In 52-week study Sitagliptin was compared to glipizide and it was found that $\mathrm{HbAlc}$ and fasting glucose decreased equally in both groups with less incidence of hypoglycaemic episodes in the sitagliptin group. When compared for body weight, glipizide treated patients showed an increase of $1.1 \mathrm{~kg}$, whereas the patients on sitagliptin experienced a weight loss of $1.5 \mathrm{~kg} .{ }^{27} \mathrm{In}$ active-controlled trials, a vildagliptin-metformin combination therapy has been shown to produce equivalent reductions in $\mathrm{HbAlc}$ to pioglitazonemetformin and glimepiride-metformin combinations, without significant risk of hypoglycaemia and weight gain. In a vast number of clinical studies, sitagliptin and vildagliptin were well tolerated in terms of the number of adverse events and the incidence of hypoglycaemia. ${ }^{25}$

\section{Glycaemic effects of DPP-4 inhibitors as monotherapy}

A 12-week study examined vildagliptin as monotherapy in patients with a mean baseline $\mathrm{HbA1c}$ of $7.7 \% .^{28}$ vildagliptin reduced $\mathrm{HbA} 1 \mathrm{c}$ by $0.46 \%$ at $50 \mathrm{mg}$ and $0.4 \%$ at $100 \mathrm{mg}$ daily, compared to the non-significant $0.13 \%$ reduction by placebo. Another study examined vildagliptin as a single dose versus twice-daily divided doses for 24 weeks in drug-naïve patients with type 2 diabetes with a baseline $\mathrm{HbA} 1 \mathrm{c}$ of $8.4 \% .^{29} \mathrm{HbA} 1 \mathrm{c}$ was reduced by $0.7 \%$ by vildagliptin at $50 \mathrm{mg}$ twice daily and $0.9 \%$ at $100 \mathrm{mg}$ once daily.

Sitagliptin (100mg daily) was initially evaluated as monotherapy in drug-naive patients with type 2 diabetes using different doses for duration of 12 weeks. In one study ( $\mathrm{n}^{1 / 4}$ 555; mean baseline HbA1c7.7\%), HbA1c was reduced by $0.56 \%$ by sitagliptin. ${ }^{30}$

A second study ( $\mathrm{n}^{1 / 4}$ 743) examined sitagliptin (50mg twice daily) in patients with a mean baseline HbA1c of $7.8 \%$. It was found to have reduced HbA1c over 12 weeks by $0.8 \%$. These research studies thus demonstrated clinically important and efficacious DPP-4 inhibitors in improving the glycaemia as monotherapy. Patients with higher baselineHbA1c have higher reduction and there have been no difference observed among younger and older subjects and no relation to the degree of obesity in terms of efficacy of drug. ${ }^{31}$

Comparison with other agents in monotherapy, A 24-week head-to-head study compared the effect of vildagliptin (50mg twice daily, $\mathrm{n}^{1 / 4} 519$ ) with that of rosiglitazone ( $8 \mathrm{mg}$ once daily, $\left.n^{1 / 4} 267\right)$ in subjects with type 2 diabetes with a mean baseline $\mathrm{HbA} 1 \mathrm{c}$ of $8.7 \% .^{32} \mathrm{HbA} 1 \mathrm{c}$ was reduced by $1.1 \%$ by vildagliptin versus $1.3 \%$ by rosiglitazone. Furthermore, a 52-week study examined the influence of vildagliptin (50mg twice daily; $\mathrm{n}^{1 / 4} 526$ ) versus metformin (1g twice daily; $\mathrm{n}^{1 / 4} 254$ ) in subjects with type 2 diabetes with a mean baseline HbA1c of $8.7 \% .{ }^{33}$ Vildagliptin reduced $\mathrm{HbA} 1 \mathrm{c}$ by $1.0 \%$, which was not non-inferior to metformin, which reduced HbA1c by $1.4 \%$.

\section{Glycaemic effects of DPP-4 inhibitors in combination therapy}

Combination of DPP4 inhibitors with different oral hypoglycaemic agents have been discussed as follows.

\section{Combination with metformin}

In a 12 week study ( $n^{1 / 4}$ 107) with combination of vildagliptin and metformin in patients with a mean baseline $\mathrm{HbA} 1 \mathrm{c}$ of $7.8 \%$, there was reduction of $\mathrm{HbA} 1 \mathrm{c}$ levels by $0.7 \%$, however an extended study of 40 -week period $\left(\mathrm{n}^{1 / 4} 71\right)$, vildagliptin reduced $\mathrm{HbA} 1 \mathrm{c}$ by $1.1 \%$ versus placebo. Another 24-week study observed similar reduction of HbA1c (by 1.1\%) in patients (n 1/4 362) with a mean baseline HbA1c of $7.5 \%$ who were treated with combination of vildagliptin (100mg once daily) and metformin. ${ }^{34}$ Sitagliptin at $100 \mathrm{mg}$ daily was added to ongoing metformin in subjects with a mean baseline HbA1c of $8.0 \%\left(n^{1 / 4} 701\right) .{ }^{35}$ After 24 weeks, HbA1c was reduced by the use of this combination by $0.65 \%$ compared to treatment with metformin alone.

\section{Comparison with other agents as add-on to metformin}

A study compared the effect of vildagliptin (50mg twice daily; $\mathrm{n}^{1 / 4} 295$ ) to that of pioglitazone (30mg once daily; 
$\mathrm{n}^{1 / 4}$ 281) when combined with ongoing metformin therapy in subjects with baseline $\mathrm{HbA} 1 \mathrm{c}$ of $8.4 \%$. After 24 weeks, both vildagliptin (by $0.9 \%$ ) and pioglitazone (by $1.0 \%$ ) had reduced $\mathrm{HbA} 1 \mathrm{c}$ with no significant difference between the groups. Another active-controlled study compared the effect of sitagliptin (100mg daily) plus metformin versus glipizide (up to $20 \mathrm{mg}$ daily) plus metformin in subjects ( $\mathrm{n}^{1 / 4}$ 1172) with a mean baseline HbA1c of $7.5 \%$. The $\mathrm{HbA} 1 \mathrm{c}$ was reduced by $0.67 \%$ in both groups. ${ }^{36}$

Hence, DPP-4 inhibition shows an efficient effect in improving glycaemic control as sulphonylureas and thiazolidinediones when added to metformin.

\section{Combination with thizolidinediones}

A comparative study on 463 patients with baseline HbA1c of $8.7 \%$ was conducted with vildagliptin $50 \mathrm{mg}$ or $100 \mathrm{mg}$ versus placebo as add on therapy to pioglitazone at $45 \mathrm{mg}$. It was observed that $\mathrm{HbA} 1 \mathrm{c}$ was reduced by $0.8 \%$ with $50 \mathrm{mg}$, by $1.1 \%$ with $100 \mathrm{mg}$ vildagliptin versus $0.3 \%$ in the placebo group treated with pioglitazone alone. ${ }^{37} 45 \%$ of the subjects reached target for control $(<7 \%)$ at the end of the study compared to $23 \%$ of patients treated with pioglitazone alone.

\section{Combination with sulfonylurea}

A 24-week study in 515 patients with a mean baseline $\mathrm{HbA} 1 \mathrm{c}$ of $8.5 \%$ was conducted where vildagliptin $(50 \mathrm{mg}$ once or twice daily) versus placebo were added to glimepiride (4mg daily). ${ }^{38}$

The Placebo-adjusted group showed $\mathrm{HbA} 1$ reduction by $0.6 \%$ as compared to $0.76 \%$ reduction shown by vildagliptin $50 \mathrm{mg}$ once daily and $50 \mathrm{mg}$ twice daily. In another study, add-on of sitagliptin (100mg daily) to glimepiride alone versus glimepiride and metformin combination in patients (n $1 / 4441$ ) with a mean baseline $\mathrm{HbA1c}$ of $8.3 \%$, demonstrated a reduction in HbA1c of $0.7 \%$ in patients given sitagliptin and glimepiride in comparison to $0.9 \%$ reduction in patients given triple therapy. ${ }^{39}$

\section{Combination with insulin}

In 24 weeks study with patients having baseline mean HbA1c $8.9 \%$, when vildagliptin was added to insulin, the mean $\mathrm{HbA} 1 \mathrm{c}$ was reduced by $0.5 \%$ in vildagliptin group versus $0.2 \%$ in the group given insulin alone. ${ }^{40}$ To summarize the effect of DPP-4 inhibitor, it reduces HbA1C by $0.6-1.15 \%$ over $24-52$ weeks duration as monotherapy, however as add on therapy with metformin, sulfonylureas and thiazolidinediones the DPP-4 inhibitors reduce $\mathrm{HbA} 1 \mathrm{C}$ by $0.6-1.1 \%$. Further, various studies showed that DPP-4 inhibitors are similar in potency to sulfonylureas and thiazolidinediones when added to metformin also, DPP-4 inhibition improves glycaemic control when combined with insulin.

\section{Safety profile}

Various DPP-4 inhibitors have been proven to be as safe and tolerable both as monotherapy and combination with other OHA. The incidence of hypoglycaemic events seen with DPP4 inhibitors were considerably less as compared to seen with other existing drugs used in treatment of type 2 DM. In a comparative study, sitagliptin was compared with glipizide both of which were administered as add on therapy to conventional metformin, it was observed that hypoglycemia was reported in $5 \%$ cases in sitagliptin group versus $32 \%$ cases in glipizide group. ${ }^{41}$ In another study in which vildagliptin was added to insulin, the incidences of hypoglycemia were less (113) in vildagliptin group as compared to placebo group (185). ${ }^{42}$ Thus it is clearly observed that DPP-4 inhibitors are less known for occurrence of hypoglycemia as an adverse effect. DPP4 inhibitors are considered as weight neutral, it is in contrast to weight reduction effect shown by GLP1 analogues and weight gain effect shown by sulfonylureas. A study comparing effect of sitagliptin in combination with metformin with that of glipizide in combination with metformin showed a clear difference in body weight as reduced body weight in the group treated with sitagliptin (by $1.5 \mathrm{~kg}$ ) versus increased body weight in the group treated with glipizide (by $1.1 \mathrm{~kg}$ ). ${ }^{41}$

\section{DISCUSSION}

\section{Possible long-term effects of DPP-4 inhibitors on beta- cell}

In animal models, the number of insulin-positive beta-cells in islets and the beta to alpha cell ratio in different diabetic animals was normalized by DPP-4 inhibitors. Furthermore, glucose-stimulated insulin secretion in isolated islets was found to be improved in comparison to glipizide treated mice. According to these experimental results, DPP-4 inhibitors may have the potential to delay or prevent disease progression in type 2 diabetes and to improve beta-cell mass and function. ${ }^{25}$

In mice deficient in DPP-4 (DPP-4 knockout mice)concentrations of circulating intact GLP-1 and GIP are elevated and these animals are resistant to streptozotocin (STZ)-induced beta-cell destruction. ${ }^{43}$ Preclinical studies have demonstrated that both sitagliptin and vildagliptin increased beta-cell mass in rodent models by increasing the number of replicating islet cells and reducing the number of apoptotic islet cells as assessed in neonatal rats and high-fat diet STZ-induced diabetic mice as models for rapid beta-cell turnover and growth.

In drug naive patients, treatment with vildagliptin (in a high dose of $100 \mathrm{mg}$ twice daily) improved beta-cell function by increasing insulin secretion at any glucose level, whereas the slope of beta-cell dose response and the potentiation factor were not affected using a mathematical model. In a similar study over 1 year of vildagliptin as addon therapy to metformin, an improvement was 
demonstrated in beta-cell function, with enhanced postprandial insulin secretion and increased insulin sensitivity and disposition index. A 12-week treatment of drug naive type 2 diabetic patients with vildagliptin $(50 \mathrm{mg}$ twice daily) restored the acute insulin response to glucose (AIRg) and the sensitivity index ( $\mathrm{Si}$ ) determined by a fast sampling intravenous glucose tolerance test. The disposition index $(\mathrm{AIRg} \times \mathrm{Si})$ increased greater than fourfold, and part of its effect remained after a 2-4-week washout, suggesting that vildagliptin may exert some disease-modifying effect. ${ }^{44}$ In summary, more study data are needed to evaluate the effect of DPP-4 inhibitors on beta-cell function, disease progression and beta-cell mass.

\section{CONCLUSION}

Inhibition of DPP-4 enzyme has been proven as a promising aspect in the treatment of type 2 diabetes and various drugs inhibiting DPP4 enzymes have been developed now. They are highly recommended in the treatment of Type 2 DM both as monotherapy as well as combination therapy. Drugs like vildagliptin, sitagliptin and saxagliptin are highly effective in reducing raised blood sugar and thereafter maintaining its normal level in all type 2 DM patients. Major role of DPP4 inhibitors remain as add on therapy to metformin in patients with inadequate glycemic control with metformin alone, however patients not tolerating metformin or if it is contraindicated can be managed with DPP4 inhibitor as monotherapy. Furthermore, DPP-4 inhibitors also have significant role in replacing sulfonylurease or thiozolidindione and also as add on therapy to these drugs if glycemic control is poor with individual drugs. However, therapeutic potential of DPP-4 inhibitor in combination with insulin needs to be explored in future.

Funding: No funding sources Conflict of interest: None declared

Ethical approval: Not required

\section{REFERENCES}

1. Aronoff SL, Berkowitz K, Shreiner B, Want L. Glucose metabolism and regulation: beyond insulin and glucagon. Diabetes Spectrum. 2004;17:183-90.

2. Gallwitz B. New therapeutic strategies for the treatment of type 2 diabetes mellitus based on incretins. Rev Diabet Stud. 2005;2(2):61-9.

3. Drucker DJ, Nauck MA. The incretin system: glucagon-like peptide-1 receptor agonists and dipeptidyl peptidase- 4 inhibitors in type 2 diabetes. Lancet. 2006;368:1696-705.

4. Farilla L, Bulotta A, Hirshberg B, Li Calzi S, Khoury $\mathrm{N}$, Noushmehr $\mathrm{H}$, et al. Glucagon-like peptide 1 inhibits cell apoptosis and improves glucose responsiveness of freshly isolated human islets. Endocrinology. 2003 Dec 1;144(12):5149-58.

5. Baggio LL, Drucker DJ. Biology of incretins: GLP-1 and GIP. Gastroenterology. 2007;132:2131-57.
6. Boyle PJ, Freeman JS. Application of incretin mimetics and dipeptidyl peptidase IV inhibitors in managing type 2 diabetes mellitus. J Am Osteopath Assoc. 2007;107(suppl 3):S10-S16.

7. Vaag AA, Holst JJ, Vølund A, Beck-Nielsen HB. Gut incretin hormones in identical twins discordant for non-insulin-dependent diabetes mellitus (NIDDM)evidence for decreased glucagon-like peptide-1 secretion during oral glucose ingestion in NIDDM twins. Eur J Endocrinol. 1996;135:425-32.27.

8. Nathan DM, Schreiber E, Fogel H, Mojsov S, Habener JF. Insulinotropic action of glucagonlike peptide-I-(7$37)$ in diabetic and nondiabetic subjects. Diabetes Care. 1992;15:270-6.

9. Lynn FC, Thompson SA, Pospisilik JA, Ehses JA, Hinke SA, Pamir N, et al. A novel pathway for regulation of glucose-dependent insulinotropic polypeptide (GIP) receptor expression in $\beta$ cells. The FASEB J. 2003 Jan;17(1):91-3.

10. Lambeir AM, Durinx C, Scharpe S, De Meester I. Dipeptidyl-peptidase IV from bench to bedside: an update on structural properties, functions, and clinical aspects of the enzyme DPP IV. Crit Rev Clin Lab Sci. 2003;40:209-4.

11. Miller S, St. Sitagliptin OEL. a dipeptidyl peptidase IV inhibitor for the treatment of type 2 diabetes. Ann Pharmacother. 2006;40:1336-43.

12. Blech S, Ludwig-Schwellinger E, Grafe-Mody EU, Withopf B, Wagner K. The metabolism and disposition of the oral dipeptidyl peptidase-4 inhibitor, linagliptin, in humans. Drug Metab Dispos. 2010;38:667-78.

13. European Medicines Agency (EMEA). Galvus (vildagliptin)- European public assessment report (EPAR)- scientific discussion. Available at: http://www.emea.europa.eu/humandocs/PDFs/EPAR/ galvus/H- 771-en6.pdf. Accessed 5 July 2010.

14. European Medicines Agency (EMEA). Onglyza (saxagliptin)- European public assessment report (EPAR)- CHMP Assessment Report. Available at: http://www.emea.europa.eu/humandocs/PDFs/EPAR/ onglyza/H-1039-en6.pdf. Accessed 5 July 2010.

15. Feng J, Zhang Z, Wallace MB, Stafford JA, Kaldor SW, Kassel DB, et al. Discovery of alogliptin: a potent, selective, bioavailable, and efficacious inhibitor of dipeptidyl peptidase IV. J Med Chem. 2007;50:2297-300.

16. Eckhardt M, Langkopf E, Mark M, Tadayyon M, Thomas L, Nar H, et al. 8-(3-(R)-aminopiperidin-1yl)-7-but-2-ynyl-3-methyl-1-(4-methyl-quinazolin-2ylmethyl)-3, 7-dihydropurine-2, 6-dione (BI 1356), a highly potent, selective, long-acting, and orally bioavailable DPP-4 inhibitor for the treatment of type 2 diabetes. J Med Chem. 2007;50:6450-3.

17. Kim YB, Kopcho LM, Kirby MS, Hamann LG, Weigelt CA, Metzler WJ, et al. Mechanism of GlyPro-pNA cleavage catalyzed by dipeptidyl peptidaseIV and its inhibition by saxagliptin (BMS-477118). Arch Biochem Biophys. 2006;445:9-18. 
18. Neumiller JJ. Differential chemistry (structure), mechanism of action, and pharmacology of GLP-1 receptor agonists and DPP-4 inhibitors. J Am Pharm Assoc. 2009;49(Suppl. 1):S16-29.

19. Bristol-Myers Squibb. Onglyza (saxagliptin) $5 \mathrm{mg}$ filmcoated tablets. Summary of Product Characteristics. Last date of revision: 09 October 2009. Available

at: http://emc.medicines.org.uk/medicine/22315/SPC/On glyza+5mg+film-coated+tablets [accessed 06.10].

20. Thomas L, Eckhardt M, Langkopf E, Tadayyon M, Himmelsbach F, Mark M. (R)-8-(3-amino-piperidin1-yl)-7-but-2-ynyl-3-methyl-1-(4-methyl-quinazolin2-ylmethyl)-3,7-dihydro-purine-2,6-dione (BI 1356), a novel xanthinebaseddipeptidyl peptidase 4 inhibitor, has a superior potency and longer duration of action compared with other dipeptidyl peptidase-4 inhibitors. J Pharmacol Exp Ther. 2008;325:175-82.

21. Thomas L, Tadayyon M, Mark M. Chronic treatment with the dipeptidyl peptidase-4 inhibitor BI 1356 [(R)8-(3-aminopiperidin-1-yl)-7-but-2-ynyl-3-methyl-1(4-methylquinazolin- 2-ylmethyl)-3,7-dihydropurine-2,6-dione] increases basal glucagon-like peptide-1 and improves glycemic control in diabetic rodent models. J Pharmacol Exp Ther. 2009;328:55663.

22. Deacon CF, Ahren B, Holst JJ. Inhibitors of dipeptidyl peptidase IV: a novel approach for the prevention and treatment of Type 2 diabetes? Expert Opin Investig Drugs. 2004;13:1091-102.

23. Drucker DJ, Nauck MA. The incretin system: glucagon-like peptide-1 receptor agonist and dipeptidyl peptidase- 4 inhibitors in type 2 diabetes. Lancet. 2006;368:1696-705.

24. Gallwitz B. Sitagliptin: profile of a novel DPP-4 inhibitor for the treatment of type 2 diabetes. Drugs Today (Barc). 2007;43:13-25.

25. Ristic S, Bates PC. Vildagliptin: a novel DPP-4 inhibitor with pancreatic islet enhancement activity for treatment of patients with type 2 diabetes. Drugs Today (Barc). 2006;42:519-31.

26. Raz I, Chen Y, Wu M, Hussain S, Kaufman KD, Amatruda JM, et al. Efficacy and safety of sitagliptin added to ongoing metformin therapy in patients with type 2 diabetes. Curr Med Res Opin. 2008 Feb $1 ; 24(2): 537-50$.

27. Nauck M, Meininger G, Sheng DO, Terranella L, Stein PP. Sitagliptin Study 024 Group. Efficacy and safety of the dipeptidyl peptidase-4 inhibitor, sitagliptin, compared with the sulfonylurea, glipizide, in patients with type 2 diabetes inadequately controlled on metformin alone: a randomized, doubleblind, non-inferiority trial. Diabetes, Diabetes Obes Metab. 2007;9:194-205.

28. Ristic S, Byiers S, Foley J, Holmes D. Improved glycaemic control with dipeptidyl peptidase-4 inhibition in patients with type 2 diabetes: vildagliptin (LAF237) dose response. Diabetes Obes Metab. 2005 Nov;7(6):692-8.
29. Pi-Sunyer FX, Schweizer A, Mills D, Dejager S. Efficacy and tolerability of vildagliptin monotherapy in drug-naive patients with type 2 diabetes. Diabetes research and clinical practice. 2007 Apr 1;76(1):1328.

30. Hanefeld M, Herman GA, Wu M, Mickel C, Sanchez M, Stein PP. Sitagliptin Study 014 Investigators. Once-daily sitagliptin, a dipeptidyl peptidase-4 inhibitor, for the treatment of patients with type 2 diabetes. Current medical research and opinion. 2007 Jun 1;23(6):1329-39.

31. Pratley RE, Rosenstock J, Pi-Sunyer FX, Banerji MA, Schweizer A, Couturier A, et al. Management of type 2 diabetes in treatment-naive elderly patients: benefits and risks of vildagliptin monotherapy. Diabetes Care. 2007;30:3017-22.

32. Rosenstock J, Baron MA, Dejager S, Mills D, Schweizer A. Comparison of vildagliptin and rosiglitazone monotherapy in patients with type 2 diabetes: a 24-week, double-blind, randomized trial. Diabetes care. 2007 Feb 1;30(2):217-23.

33. Schweizer A, Couturier A, Foley JE, Dejager S. Comparison between vildagliptin and metformin to sustain reductions in $\mathrm{HbA1c}$ over 1 year in drug-naïve patients with Type 2 diabetes. Diabetic Medicine. 2007 Sep;24(9):955-61.

34. Bosi E, Camisasca RP, Collober C, Rochotte E, Garber AJ. Effects of vildagliptin on glucose control over 24 weeks in patients with type 2 diabetes inadequately controlled with metformin. Diabetes care. 2007 Feb 2.

35. Charbonnel B, Karasik A, Liu J, Wu M, Meininger G. Efficacy and safety of the dipeptidyl peptidase-4 inhibitor sitagliptin added to ongoing metformin therapy in patients with type 2 diabetes inadequately controlled with metformin alone. Diabetes care. 2006 Dec 1;29(12):2638-43.

36. Scott R, Loeys T, Davies MJ, Engel SS. Efficacy and safety of sitagliptin when added to ongoing metformin therapy in patients with type 2 diabetes. Diabetes Obes Metab. 2008 Oct 1;10(10):959-69.

37. Garber AJ, Schweizer A, Baron MA, Rochotte E, Dejager S. Vildagliptin in combination with pioglitazone improves glycaemic control in patients with type 2 diabetes failing thiazolidinedione monotherapy: a randomized, placebo-controlled study. Diabetes Obes Metab. 2007 Mar;9(2):166-74.

38. Garber AJ, Foley JE, Banerji MA, Ebeling P, Gudbjörnsdottir S, Camisasca RP, et al. Effects of vildagliptin on glucose control in patients with type 2 diabetes inadequately controlled with a sulphonylurea. Diabetes Obes Metab. 2008 Nov;10(11):1047-56.

39. Hermansen K, Kipnes M, Luo E, Fanurik D, Khatami H, Stein P. Sitagliptin Study 035 Group. Efficacy and safety of the dipeptidyl peptidase-4 inhibitor, sitagliptin, in patients with type 2 diabetes mellitus inadequately controlled on glimepiride alone or on glimepiride and metformin. Diabetes Obes Metab. 2007;9:733-45. 
40. Fonseca V, Schweizer A, Albrecht D, Baron MA, Chang I, Dejager S. Addition of vildagliptin to insulin improves glycaemic control in type 2 diabetes. Diabetologia. 2007 Jun 1;50(6):1148-55

41. Burkey BF, Hoffmann PK, Hassiepen U, Trappe J, Juedes M, Foley JE. Adverse effects of dipeptidyl peptidases 8 and 9 inhibition in rodents revisited. Diabetes Obes Metab. 2008 Nov 1;10(11):1057-61.

42. Piteau S, Olver A, Kim SJ, Winter K, Pospisilik JA, Lynn F, et al. Reversal of islet GIP receptor downregulation and resistance to GIP by reducing hyperglycemia in the Zucker rat. Biochemical and biophysical research communications. 2007 Nov 3;362(4):1007-12.

43. Conarello SL, Li Z, Ronan J, Roy RS, Zhu L, Jiang G, et al. Mice lacking dipeptidyl peptidase IV are protected against obesity and insulin resistance. Proceedings of the National Academy of Sciences. 2003 May 27;100(11):6825-30.

44. Alvin C. Powers and David D'Alessio. Endocine Pancreas and Pharmacotherapy of Diabetes Mellitus and Hypoglycemia. In: Goodman and Gilman's The Pharmacological Basis of Therapeutics, $13^{\text {th }}$ ed. McGraw Hill Medical, New York; 2017:863-886.

Cite this article as: Ramesh, Gupta DD. Role of DPP-4 inhibitors in the management of type 2 diabetes. Int J Basic Clin Pharmacol 2018;7:2488-95. 